\title{
Rebus Approach of Entrepreneurship Learning
}

\author{
Jelena Jovanovic \\ University of Montenegro, Montenegro \\ Zdravko Krivokapic \\ University of Montenegro, Montenegro \\ Aleksandar Vujovic \\ University of Montenegro, Montenegro
}

\begin{abstract}
In the Western Balkan countries young generations prefer "safe" employment at public enterprises. Student's awareness and appreciation of own entrepreneurship potentials are low and because of that they mostly don't start their own business. It is obvious that there is a need to promote learning about entrepreneurship at the HEls and need to strengthen capacities of university lecturers to deal with entrepreneurship topics. The Erasmus REBUS project is established with aims to promote entrepreneurship competences of graduates of engineering studies from the Western Balkan countries and Russia, through development, test, validation and mainstreaming of holistic and needs driven open learning modules. The project enabled strong support to address a challenge of bringing entrepreneurship into HEls and establishing the interface between higher education and practical business context based on cooperation network of EU and Western Balkan countries. The paper is focused on Rebus approach of entrepreneurship learning in Western Balkan countries. REBUS project promote development of various entrepreneurship training modules and their integration into existing or new curricula at the HEls, creation and adoption of entrepreneurship competence validation system, implementation and evaluation of the training modules and competence validation system. There will be also shown how Rebus project is implemented at the University of Montenegro, with focus at the process of learning about entrepreneurship, process of definition and realization of students' project and validation of their knowledge.
\end{abstract}

Keywords: Entrepreneurship, competences, blended learning, validation JEL classification: L26

\section{Introduction}

The concept of entrepreneurship is mostly related to the process of implementing a new business arrangement (Peković et al., 2017). Entrepreneurship represents a tendency towards achieving economic growth (e.g. Lumpkin et al., 1996). Entrepreneurship is looking for opportunities to achieve economic growth, regardless of the available resources at the moment. Entrepreneurship involves the observation of new ideas and business opportunities and entering a new business venture, and entrepreneurs are those who launch a new business venture. Entrepreneurship can also be viewed as an activity aimed at launching, organizing and innovating the business of the organization, with the main goal of creating a new market and generating profit (Hitt et al., 2017). The importance of entrepreneurship is illustrated by the extraordinary figure that points out that $75 \%$ of jobs in the world are created 
through entrepreneurial ventures (Vujović et al., 2014). One of the most important elements of entrepreneurship is to have experience and continuous training and learning (Bae et al., 2014; Robinson et al., 2016).

The Erasmus REBUS project is aimed at promoting entrepreneurship competences of graduates of engineering studies from the Western Balkan countries and Russia through the development, testing, validation and mainstreaming of holistic and needs driven open learning modules. The project enabled strong support to address the challenge of bringing entrepreneurship into HEls and establishing an interface between higher education and a practical business context based on a network of cooperation between the EU and the Western Balkan countries. The project developed a concept to support the development of key competences for employability that will guarantee more flexibility in the labor force and allow for faster adaptation to constant changes in a more interconnected world (Rebus project, 2018).

\section{Rebus concept}

The Rebus project aimed at encouraging learning about entrepreneurship among students is based on the following facts:

- Entrepreneurial learning is mostly informal learning

- Entrepreneurship is rather a set of competences than a qualification

- The development of entrepreneurial competences can be validated (assessed and evidenced)

- Entrepreneurial learning affords ,innovative" and „holistic" ways of learning

The Rebus project is predominantly focused on developing entrepreneurial competences among students of technical and ICT studies because these students are considered to have the greatest capacity and creativity for developing their own business. Partners of the Western Balkan project, under the mentorship of the EU partner, defined their programs to encourage entrepreneurship in university units.

As a first step, the obligation to change the ECTS catalogue of classes that can naturally be related to this topic in the amount of not more than $15 \%$ is required, so that it would not require re-accreditation of study programs. In addition, all partners were obliged to define their own training programs for a selected group of 30 students. Student training projects had to be structured in following different learning modalities [Rebus Project]:

- F2F

- e-learning and

- learning projects

and following different phases:

- Phase 1 (Introduction and theory) in your institution

- Phase 2: (Practical learning phase)

- Phase 3: Feed-Back phase (presentation, evaluation, assessment, documentation)

as it is shown on Figure 1. 
Figure 1

Rebus Learning Pathway

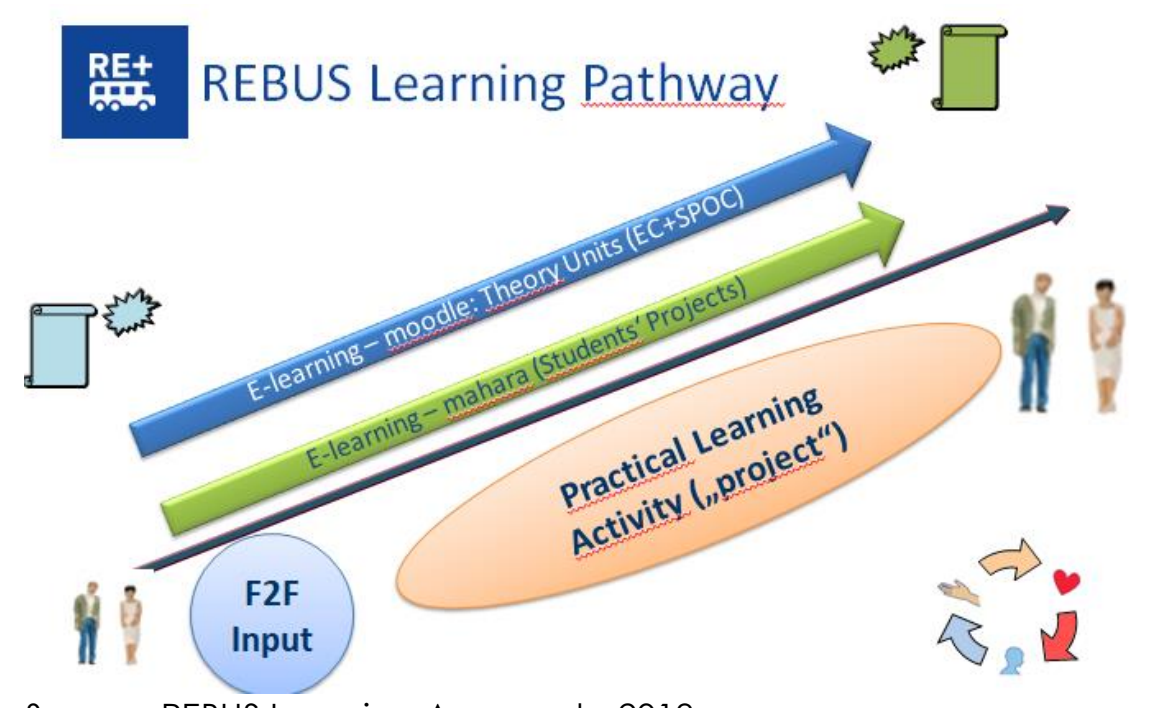

Source: REBUS Learning Approach, 2018

The project site which available transparency of learning material for e-learning under the name Mahara was created by the EU partner (http://mahara.learningrebus.net/). The site has provided key presentations by the EU partners on the most important topics in this field:

- Personal comptences

- Intercultural competencies and

- Entrepreneurship

In addition, professors engaged in the project (trainers) trained by the EU partner have created their own presentations that were put on the same site. Each registered student has access to all these presentations and his / her learning is enabled through the MOODLE system where they also have access.

One of the biggest challenges in the implementation of the project is the definition and realization of student projects. Students define themes of projects that promote their entrepreneurial competencies. They also define work teams. Each working team has a mentor-professor in the project implementation.

Students have acquired their knowledge through F2F (face to face) learning, distance learning and engaging in selected business systems through student practice, transcending their student projects. They work on projects in consultation with professors (trainers) appointed for their mentors.

In order to achieve all of Rebus objectives, there were developed a pathway to guide trip through preparation of student's project. It is a step-by-step procedure (REBUS Learning Approach, 2018):

1. PLAN - At the beginning of the practical learning student should describe the project that he wants to realize. Already at this phase student can reflect on the competences that he may acquire during his project and fill in a first questionnaire about them.

2. DO - During his practical learning phase he can keep a logbook in which he can record his experiences (he is invited to collect the proofs of his work also in his personal e-portfolio; he can create pages and collections and publish them in his section on Mahara site).

3. CHECK - At the end of his learning project he will be invited to assess himself on the development of his entrepreneurial competences. He will do that with 
the help of the LEVEL5 validation system, an easy to use validation tool. At this stage he will warmly invited to discuss his findings with his mentor.

Based on the results that he will send to his organizing REBUS partner an individual LEVEL5 certificate will be issued. He can add this certificate to his CV or portfolio as a valuable evidence of his entrepreneurs' competences!

For all students from NON-EU countries, two-week training is planned in prestigious university centers in EU countries. After this training and the gathering of additional knowledge about the methods and techniques of entrepreneurship and other tools specific to the realization of their projects after the completion of the training, they are obliged to submit completed projects.

After the completed training (F2F, E-larning and practical training), the validation of competences is carried out. Validation of competences is another big challenge in the implementation of the Rebus project.

Entrepreneurship competences have extreme importance in EU accession and neighbouring countries because employers from these countries recognize such soft skills and competences of graduated students.

\section{Level 5 - Validation of entrepreneurship competences}

According Rebus project a competence is define as ability to apply a synthesis of knowledge, skills and attitudes as it shown on Figure 2.

Figure 2

Assessment of Competences

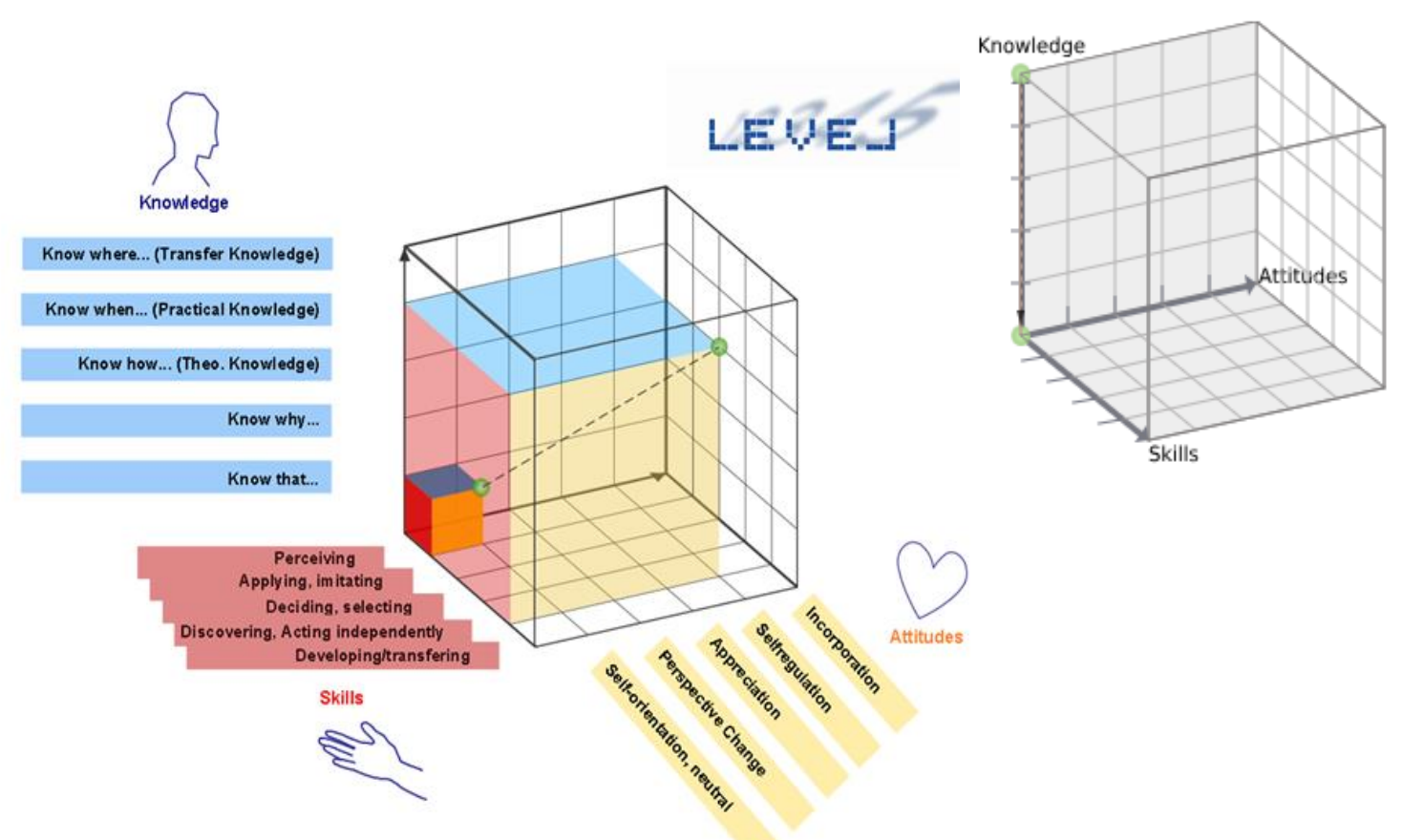

Source: REBUS Learning Approach, 2018

Knowledge is defined as theoretical and practical knowledge of the application of various tools and strategies such as project management, marketing, leadership, economic principles...

Skills are defined as the ability to apply different tools and strategies in accordance with the situation and goals to be met, the ability to assess and analyze 
opportunities and risks, take responsibility for realized activities and the ability to promote their ideas.

Attitudes include proactivity, motivation to take initiative, willingness to take risks, all in order to achieve the set goal.

Students carry out self-assessment of all these categories through 5 levels of grades as it shown in Table 1 (REBUS Learning Approach, 2018).

Table 1

Levels of Self-Assessment

\begin{tabular}{cccc}
\hline LEVEL & KNOWLEDGE & $\begin{array}{c}\text { SKILLS } \\
\text { Capabilities }\end{array}$ & $\begin{array}{c}\text { ATTITUDES } \\
\text { Emotions/Values }\end{array}$ \\
\hline 5 & Know where else... & Transfering & Incorporation \\
4 & Know when... & Discovering & Commitment \\
3 & Know how... & Deciding & Appreciation \\
2 & Know why... & Imitating & Perspective taking \\
1 & Know-that... & Perceiving & Neutral \\
\hline
\end{tabular}

Source: REBUS Learning Approach, 2018

Students will realize two self-assessments:

- First assessment and

- Second assessment

The first assessment will be performed before leaving for training in the EU countries, while the second assessment will be carried out after the training and after realization of the defined student projects.

The first assessment can be realized for different types of competencies as following:

- Intercultural communication

- Leadership

- Communication

- Teamworking

- Client orientation

- Project management

- Planning and resource management

- Flexibility / adaptability

- Networking

- Evaluating / reflecting

- Problem solving

- Creativity

- Critical thinking

- Entrepreneurship

Compulsory competencies for which the First Assessment will be exercised in all non-EU countries are: Intercultural communication and Entrepreneurship.

Each partner can then independently choose some other competencies from the offered list.

The appearance of the form for self-assessment of students is shown in Figure 3. By choosing the grade for each category of knowledge of the chosen competence, an additional window opens where they have to fill a description which confirms the assessment. 
Figure 2

Assessment of Competences

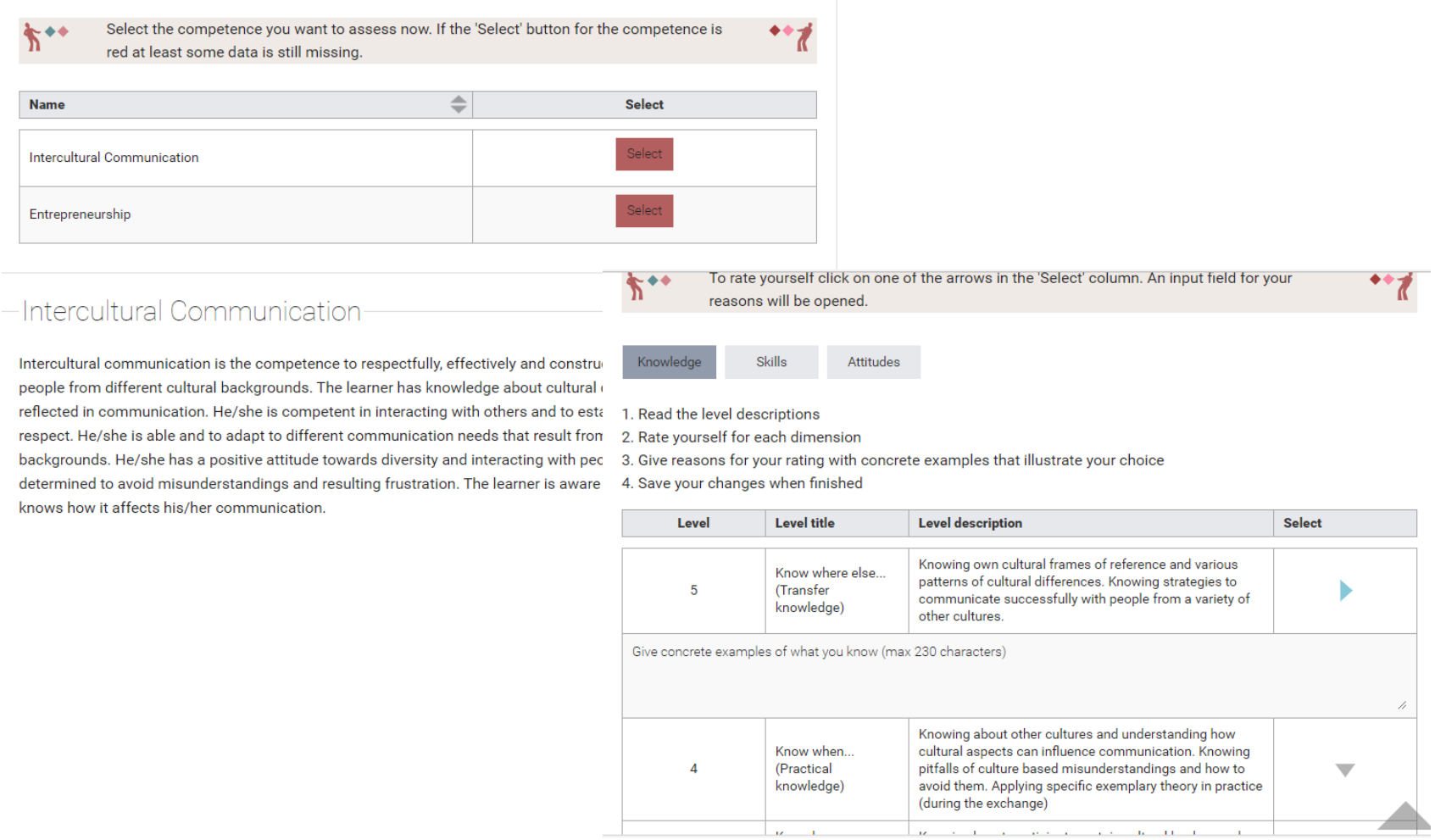

Source: REBUS project (2018)

After conducting the assessment by all students, the issuance of certificates will be enabled. Fourteen students were selected in Montenegro to attend training on entrepreneurship in Italy, after which they will be able to complete their projects and pass the Second Assessment. The First assessment will pass all 30 selected UCG students. Each validation of competencies results in the issuance of a certificate that should be valid for CV of candidates.

\section{Conclusion}

Employers in the EU countries are increasingly demanding in terms of the competences of those who are hiring (Mitchelmore et al., 2010). Namely, some other competences are required, besides formal education. Thus, they are increasingly focusing on the interests of employers of the so-called soft skills which are in relation to creative thinking and entrepreneurship. The Recommendation on Key Competences 2006/92 (European Commission, 2006) related to lifelong learning points to the importance of these competences in employment, and therefore the development of entrepreneurship competences is of a great importance for the accession of non-EU countries to the European Union.

The paper highlights the importance of the development of entrepreneurial competences among students mainly ICT and technical studies, which are expected to independently create sophisticated businesses and to contribute to the most innovative activities in the organizations where they are employed. Accordingly, the Rebus project gave a very interesting approach to the development of entrepreneurial competencies, with the development of its own student entrepreneurial projects in cooperation with enterprises and mentors-professors. A 
special contribution of the project is in establishing a system for validating the competencies of the so-called Level 5, which enables students to obtain a certificate of acquired entrepreneurial competencies at the end of the course. It can be very useful for their $\mathrm{CV}$ and future employment, especially with employers who value the so-called soft skills. Also, the experience that students acquire in the realization of their own projects and on training in EU countries through the Rebus project will certainly contribute to their entrepreneurial competencies and possibly enale development of their ideas for own business.

\section{References}

1. Bae, T. J., Qian, S., Miao, C., Fiet, J. O. (2014), "The Relationship between Entrepreneurship Education and Entrepreneurial Intentions: A Meta-Analytic Review", Entrepreneurship theory and practice, Vol. 38, No. 2, pp. 217-254.

2. European Commission (2006), "Recommendation of the European Parliament and of the Council of 18 December 2006 on key competences for lifelong learning", available at:

https://eur-lex.europa.eu/legal-content/EN/TXT/?uri=celex\%3A32006H0962 (19 August 2018)

3. Hitt, M., Duane Ireland, R. (2017), "The intersection of entrepreneurship and strategic management research", in Sexton, D. L., Landström, H. (Eds.), The Blackwell handbook of entrepreneurship, Wiley Online Library, pp. 45-63.

4. Lumpkin, G. T., Dess, G. G. (1996), "Clarifying the entrepreneurial orientation construct and linking it to performance", Academy of management Review, Vol. 21, No. 1, pp. 135-172.

5. Mitchelmore, S., Rowley, J. (2010), "Entrepreneurial competencies: a literature review and development agenda", International journal of entrepreneurial Behavior \& Research, Vol. 16, No. 2, pp. 92-111.

6. Peković, J. Jovanović, Z. Krivokapić, A. Vujović (2017), „The state of Enterpreneurship and innovativeness in Montenegro", Book of abstracts of the ENTerprise Research InNOVAtion Conference - ENTRENOVA, 7-9 September 2017, Dubrovnik, Croatia, Vol. 3, No. 1, p.96-97.

7. REBUS Learning Approach (2018), available at: http://mahara.learningrebus.net/ (19 August 2018) ReBUS project (2018), available at: http://www.rebusproject.net/ (19 August 2018)

8. Robinson, S., Neergaard, H., Tanggaard, L., Krueger, N. F. (2016), "New horizons in entrepreneurship education: from teacher-led to student-centered learning", Education+Training, Vol. 58, No. 7/8, pp. 661-683.

9. Vujović, A., Perović, M., Krivokapić, Z., Jovanović, J. (2014), Industrijski inženjering (Industrial Engineering), Univerzitet Crne Gore, Mašinski fakultet Podgorica. 


\section{About the authors}

Dr. Jelena Jovanovic has Ph.D. at the Faculty of Mechanical Engineering Podgorica. She is Assistant Professor at the University of Montenegro. Her research interests are within the fields of Managements System standards and Performance Management System. She was consultant in more than 15 projects related to Management Systems implementation according ISO 9001, ISO 14001, ISO 17025, ISO 17020 standards and HACCP. She was engaged in many scientific research projects. She published more than 40 articles in international journals and international conferences and more than 50 articles in national journals and national conferences. The author can be contacted at sjelena@-com.me.

Zdravko Krivokapic is Doctor of Philosophy - Doctor of Science in Engineering from the Faculty of Mechanical Engineering. He is Full professor at University of Montenegro. Actively works with quality, quality management system, quality of education, informatics and accreditation. He is President of Board of Accreditation Body of Montenegro. He is member of Board for establishment and improvement of quality system of University of Montenegro. He is a president of national Conference of Quality (SQM) and International Quality Conference (ICQME). He is editor of International Journal for Quality Research. The author can be contacted at zdravkok@ac.me.

Aleksandar J. Vujovic, graduated at the Faculty of Mechanical Engineering in Podgorica in 2000, at Department of Production Engineering. Master's thesis entitled "Nonconformity macro control models as a basis for improving the QMS", defended at the Faculty of Mechanical Engineering in Podgorica in 2004. He earned his doctorate at the Faculty of Mechanical Engineering in Podgorica in 2008. For his doctoral dissertation was awarded with the "Trimo". From 2000 to 2008 he worked as a teaching assistant, when he became a professor of: industrial engineering, flexible manufacturing systems, integrated systems management expertise and laboratory practice. The author can be contacted at aleksv@ac.me. 